Vol. 17 (2008): 289-306.

\title{
Review article \\ Spring Cereals: From Dynamic Ideotypes to Cultivars in Northern Latitudes
}

\author{
Pirjo Mäkelä ${ }^{1 *}$, Susanna Muurinen ${ }^{2}$ and Pirjo Peltonen-Sainio ${ }^{3}$ \\ ${ }^{1}$ Department of Applied Biology, Crop Science, PO Box 27, FI-00014 University of Helsinki, Finland, \\ ${ }^{2}$ Sugarbeet Research Centre, Toivonlinnantie 518, FI-21500, Piikkiö, Finland \\ ${ }^{3}$ MTT Agrifood Research Finland, Plant Production Research, FI-31600 Jokioinen, Finland \\ "e-mail: pirjo.makela@helsinki.fi
}

\begin{abstract}
The ideotype of a crop is a model of a plant community where all necessary and beneficial traits for crop performance in a particular environment are combined. It is important to consider the environment when developing an ideotype since climatic, edaphic and agronomic features of the target region have a major role in determining crop performance. New technologies, high yielding cultivars, irrigation and water management, plant protection materials and more skilful farm management practices have increased yields and yield potentials on cereals in Finland as in many other countries. In this paper we aim to summarize traits which would be useful from the farmers' perspective. The most important trait is increased early vigour of spring cereals, including faster rate of early development and increased leaf area to improve both the resource capture of the canopy and water use efficiency. Introduction of dwarfing genes would improve lodging resistance and harvest index due to improved partitioning of dry matter into grains whereas longer coleoptiles would improve emergence and seedling establishment. Improved ability of crops to utilize stem reserves during grain filling would increase resistance against environmental stresses. All of these traits would also increase the competitive ability of the plant against weeds as well as competition within the crop canopy and are already available from non-adapted germplasm of the various spring cereal species.
\end{abstract}

Key-words: competition, ideotype, early vigour, NUE, stem reserves, tillering, WUE, yield potential 


\section{AGRICULTURAL AND FOOD SCIENCE}

Mäkelä, P. et al. From ideotypes to cultivars in spring cereals

\section{Introduction}

We are celebrating the 40th anniversary of the ideotype concept that was first proposed by Donald (1968) as a hypothetical plant described in terms of the traits that are thought to enhance genetic yield potential. Hence, the ideotype is a model of a plant, which grows in a community (plant stand) and combines all the necessary traits that are beneficial for crop performance in a particular environment. Although the concept was formulated 40 years ago, plant breeders previously applied the same idea when deciding what to attempt, select, or change, and why. Such accumulated information has, however, often remained unpublished, and the success of selection criteria has been tested by the breakthrough and lifespan of the introduced cultivars. Use of the ideotype concept prior to its formalization even concerned our ancestors, who decided what to keep as a seed material for the next season at the dawn of agriculture and crop domestication some 10000 years ago.

New technologies, high yielding cultivars, irrigation and water management, plant protection materials and more skilful farm management practices have increased yields and yield potentials on cereals in Finland as in many other countries (Austin 1999, Slafer and Peltonen-Sainio 2001, Öfversten et al. 2004, Giunta et al. 2007). However, in many cases these improvements could be received only with heavy application of fertilizers (Clark 1990, Bumb 1995, Foulkes et al. 1998) as well as growth regulators, herbicides, fungicides and insecticides, and irrigation. Nitrogen $(\mathrm{N})$ is normally the most used and also most costly mineral nutrient required for cereal production (Clark 1990). Globally, $\mathrm{N}$ is also considered to be the second limiting factor of plant growth after water deficiency (Sadras 2005). To maintain the crop yields and high quality production under these limitations, we need to understand efficient $\mathrm{N}$ use by a crop with changing fertilization rates. Furthermore, the use of growth regulators and other chemicals is being questioned more by consumers. Therefore, both plant breeders and farmers should pay more attention to selecting cultivars which would allow decreased use of chemicals. In the case of Finland, irrigation is getting economically questionable and in several cases even impossible for farmers. In that sense, water use efficiency (WUE) and partitioning of dry matter is an issue to consider. One means to increase the yields and the quality of the yield is increased seeding rate, which increases the cost of growing a crop.

In the last few years, several reviews about the breeding strategies of field crops for certain cultivated areas have been published. Slafer et al. (2005) reviewed the most important eco-physiological traits of cereals for Mediterranean environment. In this review we have focused on the dynamic phenomena of spring cereals on the basis of agronomic traits such as early vigour, tillering, stem reserves, water use efficiency, nitrogen use efficiency (NUE) and competition in canopies with regard to high-latitude growing conditions.

\section{From static to dynamic ideotypes}

Since the introduction of the ideotype concept, such models have been adopted and developed for different crops - too numerous to be listed here - but also for e.g. horticultural crops (Langton 1991, van Lieshout 1993) and forest trees (Pyökkö and Pulkkinen 1990, Chen et al. 1994, Wu 1994). In addition to the original use of ideotypes for characterising superior capacity for grain production (Donald 1968, Rasmusson 1987, Peltonen-Sainio 1991), they can be designed for better quality (Bertholdsson 1990, van Lieshout 1993) or higher yield stability (Berry et al. 2007). Universally applicable descriptions of ideotypes are evidently utopian, so ideotypes have been developed for different regions on the basis of understanding of, e.g., the climatic, edaphic and agronomic features (Austin 1988). This has also contributed to the inevitable drift towards more dynamic characterisations of ideotypes instead of a stereotyped crop structure (see, e.g., Mock and Pearce 1975). For example, Adams (1982) stated 
Vol. 17 (2008): 289-306.

that plant architecture per se had no merit in a yield sense except when it was associated with or led to improved physiological functions. When developing dynamic models, critical elements for certain development and growth phases can be taken into account and the ideotype is the model of a crop performance in particular environment.

Even though ideotypes are traditionally used in plant breeding to aid selection, they can also be used far more broadly. In fact, development of crop management practices is also based on the idea of gaining crop stands that are expected to have superior performance compared to older practices. This is especially true when the idea of ideotype has changed to be more dynamic. Thus, development and use of ideotypes is the result of interaction between breeders, agronomists and crop physiologists (Sedgley and Belford 1991) and the concept has broader application than originally, i.e., not only in increasing genetic yield potential (Donald 1968, Rasmusson 1987), but also in realising the yield potential through crop management.

\section{Traits of a single plant and the canopy}

\section{Early vigour}

There have been several discussions about the possibilities and advantages to increase the early vigour of the crops by means of crop management and plant breeding. However, Sloane et al. (2004) stated that before investing in the promotion of early vigour, it is necessary to evaluate the relevant biomass for effective resource capture in the prevailing environment. Even though rather effective, it is not useful to increase the nitrogen input and canopy density to promote early vigour if the environment itself restricts yield formation (Sloane et al. 2004). High canopy density results in higher leaf area index (LAI) with simultaneous reduction in plant size resulting in fewer grains per spike. Moreover, increasing canopy density increases the inter-plant competition, thus reducing the leaf area development and yield potential (Botwright et al. 2002). Such a laborious breeding project may be of little use in limiting environments, although early vigour could be further increased by using gibberellic acid (GA) -sensitive dwarfing genes. Unlike GA-insensitive dwarfing genes, the GA-sensitive ones do not restrict the growth of leaf width and length. The target could be greater leaf area development at early stages of growth (Botwright et al. 2005) which could increase the resource capture. According to Richards and Lukacs (2002) the leaf area can be increased by $50 \%$ with high-vigour wheat.

Large grain size in oat (Willenborg et al. 2005), wheat (Lafond and Baker 1986) and barley (Turk and Tawaha 2002) results in faster germination and improved canopy establishment, especially when spring moisture is limited, since the time for emergence decreases and the plant development rate increases. Moreover, tiller number and leaf dimensions increased with plant dry weight up to $21 \%$ and leaf area up to $15 \%$ when grain size was increased by only $10 \mathrm{mg}$ (Richards and Lukacs 2002). Lopez-Castaneda et al. (1996) showed that the most important factor ensuring early growth was the embryo size which accounted for $90 \%$ of the variation in vigour between small grain species. This is important under Finnish conditions with uneven spring precipitation and therefore there are grain size recommendations for certified seed. More attention should be paid in embryo size of species. However, the faster rate of development associated with seed size may either last until a limiting factor strikes or last for only the period of the first two leaves (Aparicio et al. 2002) while the plant utilises the seed reserves for growth. In contrast, earlier emerging barley plants had higher dry mass even at the stem elongation stage and produced more grains and the reduction in grain number was approximately $11 \%$ for each day of delayed seedling emergence (Soetono and Donald 1980). Peltonen-Sainio (1996) showed that an eight-day difference in time of sowing resulted in a $16-43 \%$ difference in grain yield of oat, since the yield potential is formed in a very short period in spring in high latitudes. It is more important to have a longer period for formation of maximum 


\section{AGRICULTURAL AND FOOD SCIENCE}

Mäkelä, P. et al. From ideotypes to cultivars in spring cereals

number of florets instead of formation of vegetative mass (Peltonen-Sainio 1994).

The coleoptile length has an important role in canopy establishment with its components, length of sub-crown internode, the first internode and crown. It is possible to increase the germination ability of wheat from $5 \mathrm{~cm}$ up to $11 \mathrm{~cm}$ by selecting longer coleoptiles (Gooding et al. 2006). This feature is important when soil hardening occurs after sowing and when deeper sowing is preferred due to dryness of surface soil. Optimum temperature for wheat coleoptile growth is $15^{\circ} \mathrm{C}$, higher temperatures reducing the growth due to shorter duration of growth although faster growth (Gooding et al. 2006).

Early vigour is also linked to existence of the coleoptile tiller. The presence of the coleoptile tiller in wheat results in greater leaf area, probably due to increased number and size of tillers. On average the plants with a coleoptile tiller had 27\% larger leaf area and $26 \%$ higher total dry weight, resulting in an increase of growth of more than $25 \%$ (Liang and Richards 1994). The differences between barley and wheat growth have been attributed to the smaller phyllochron interval of barley and shorter period from seedling emergence to anthesis, especially in cool climates (Dofing 1992). This ensures rapid grain filling and efficient utilisation of resources. The existence of the coleoptile tiller is related to high fertility, high radiation and low temperatures, as found in northern climates.

\section{Dwarfism - limitation or potential}

The introduction of dwarfing and semi-dwarfing genes $(R h t)$ into wheat cultivars was one of the most important factors affecting the increases in harvest index (HI) and yield (Miralles and Slafer 1997). In oat, comparable $D w$-genes have been incorporated into cultivars with nearly similar results as with wheat (de Rocquigny et al. 2004). There are 20 dwarfing genes in wheat, out of which Rht1 and $R h t 2$ are most widely used around the world, $R h t 8$ and $R h t 9$ have been occasionally used in European wheat varieties, Rht15, Rht16, Rht18, Rht19 and
$R h t 20$ have potential but are not currently used in breeding, Rht 12 is dominant and Rht4, Rht6, Rht7, $R h t 11$, Rht 17 are recessive. In oat, eight dwarfing genes exist, of which only $D w 6, D w 7$, and $D w 8$ are readily available. In barley, the most promising dwarfing gene seems to be $D w f 2$ (for a review see Milach and Federizzi 2001).

Dwarf and semi-dwarf wheat cultivars have reduced stature, are photoperiod insensitive and lodging resistant (Laing and Fischer 1977), even though lodging resistance cannot completely be linked to stem height (de Rocquigny et al. 2004). In oat, the dwarfing genes limit the height of the canopy by reducing the length of internodes up to $30-50 \%$ and panicle length from 16 to $40 \%$. However, the $D w 6, D w 7$ and $D w 8$ genes all had a different effect on internode length as well as panicle length (Milach et al. 1998). Wheats with dwarfing genes are also superior to their tall parental lines in terms of yield stability and potential (Laing and Fischer 1977). However, the most widely used, GA-insensitive Rht alleles (Rht1 and Rht2) are associated with short coleoptiles due to restricted growth of cell width and length (Botwright et al. 2005). Crops with these genes show sensitivity to environmental factors at the time of emergence, such as deep sowing, lack of water and crust formation, resulting in poor canopy establishment and yield stability (Rebetzke et al. 1999). Nevertheless, Singh et al. (2001) stated that all 13 isolines of dwarf bread and durum wheats they tested yielded $10-30 \%$ higher under drought conditions than their tall counterparts. Other Rht genes, such as $R h t 8$ and $R h t 9$, result in long coleoptiles and canopies with short stature that are less sensitive to environmental stresses (Rebetzke and Richards 2000). Some dwarfing genes (e.g. Rht8) act later and hence do not affect early vigour (Ellis et al. 2004). Similarly, Peltonen-Sainio and Järvinen (1995) concluded that yield of semi-dwarf oat was not as sensitive to environmental effects as that of tall lines. Our (Mäkelä et al. 2004) earlier work indicated that semi-dwarf oats could have breeding potential due to their growth pattern and yielding ability, although their tall counterparts had higher yield as such. The dwarf varieties had more panicle-bearing tillers but the yield potential of the main shoot was 
Vol. 17 (2008): 289-306.

lower than in tall and semi-dwarf lines (Mäkelä et al. 1996). Peltonen-Sainio and Järvinen (1994, 1995), partly for that reason, suggested that higher seeding rates, up to $600-700$ seeds $\mathrm{m}^{-2}$, should be used with dwarf cultivars of oat.

Modern semi-dwarf wheat cultivars develop faster, flower earlier, form fewer, more erect leaves and have a reduced phyllochron interval than old, tall varieties (Siddique et al. 1990a, Richards 1992b). Fully dwarf cultivars, less than 70 cm height, do not show these advantages, instead showing poor growth throughout the growing period. On the other hand, cultivars over $100 \mathrm{~cm}$ are sensitive to lodging and lack of water at later growth stages (Richards 1992a, 1992b). The light interception of semi-dwarf cultivars is higher and the efficiency of conversion of photosynthetically active radiation to above-ground biomass is higher than in old, tall cultivars (Siddique et al. 1990a). Miralles and Slafer (1997) reported, however, that $R h t 1$ and $R h t 2$ alleles were associated with reduced radiation use efficiency before anthesis. According to Calderini et al. (1996) the leaf blade expansion was reduced, especially leaf length, in dwarf wheats, restricting leaf area development and thus radiation interception. Miralles and Slafer (1997) concluded that high energy conversion was maintained due to increased leaf thickness and thus leaf photosynthetic rate per unit leaf area or weight. Increased ear:stem ratio at terminal spikelet stage and anthesis, more florets/spikelet, greater floret survival and a longer grain growth period with shorter lag phase also characterise modern semi-dwarf wheat cultivars (Siddique et al. 1990a). In high-latitude conditions, vegetative growth of tall cultivars was slow, shown later as low number of florets and thus grains (Peltonen-Sainio 1993). Rht 1 and Rht 2 alleles are associated with increased number of grains per ear and per square meter as well as number of ears per plant and per square meter, based on greater number of tillers forming ears and less stem growth, whereas their tall counterparts had higher test and kernel weight (Allan 1986, Singh et al. 2001). The $R h t$ alleles apparently affect the partitioning of dry matter between the stem and the ear by affecting the gibberellin-auxin balance. The partitioning of dry matter towards the ear is notably higher with GA-insensitive cultivars (Borrell et al. 1991). Similarly, in oat, the semidwarf cultivars have increased panicle density, kernel density and harvest index (de Rocquigny et al. 2004).

The change in partitioning dry matter in aboveground plant parts reflects also in root:shoot partitioning. Modern varieties invest a smaller proportion of total biomass in roots than in shoots (Siddique et al. 1990b). According to Passioura (1983), roots consume at least twice the assimilates per unit weight of dry matter produced in comparison to the shoot system. In young plants $54 \%$ of assimilated carbon was partitioned in the roots of barley and $33 \%$ in those of wheat while during grain filling, the corresponding figures were $5 \%$ in barley and $9 \%$ in wheat (Gregory and Atwell 1991). Black seeded oat use more energy for early root growth than white seeded oat and have also proven to be more drought tolerant (Larsson and Górny 1988). Improvement in yield and WUE with modern cultivars is associated with reduced dry matter, root length density and root:shoot ratio. Siddique et al. (1990b) stated that, the difference in investing dry matter in roots or shoot between old and modern cultivars could be explained by the delayed development of stem and ear in the old cultivars. With oat, this phenomenon is not this unambiguous, since MacKey (1988) found that the root length was lower in modern cultivars, with more roots in shallow soil than from tall cultivars, whereas de Rocquigny et al. (2004) reported no clear differences in root distribution between semi-dwarf and tall oat cultivars. Even though tall wheats have higher stem weight, their carbohydrate storage and mobilisation capacity is lower than in semi-dwarf wheats during grain filling (Richards 1992b) and the same is found in oat (Peltonen-Sainio and Järvinen 1995). The dwarf cultivars partition more dry mass into the ear, whereas taller cultivars partition more dry mass to the stem, tillers and roots even at anthesis. The maximum photosynthetic rate in dwarf cultivars increased at anthesis, indicating also greater sink strength in comparison to taller cultivars (Bishop and Bugbee 1998). Richards (1992a) stated that grain yield does not depend on the presence of dwarfing genes but on the height of the plant. Rebetzke et al. (1999) proposed that 


\section{AGRICULTURAL AND FOOD SCIENCE}

Mäkelä, P. et al. From ideotypes to cultivars in spring cereals

GA-sensitive dwarfing genes could have a future yield advantage due to their improved emergence and early growth vigour.

In conclusion, it would be in Finnish farmers' interest for cereal breeding to be focused on longer coleoptile, shorter stature and more vigorous seedlings, since these factors diminish the danger of poor plant stands, uneven canopies and lodging sensitivity. Longer coleoptiles and vigorous seedling emergence would ensure that in dry springs, canopy establishment was uniform following deeper sowing and this in turn would allow more flexible sowing time which is necessary as farm size is constantly increasing. These characteristics will also lead to possibilities to increase harvest index which will result in higher and more stabile yields.

\section{Tillers - none, some, or several}

Major yield increases of spring cereals have been associated with increases in HI index due to decrease in total weight of stems rather than increases in total dry mass. By eliminating unproductive tillers in regions where more shoots are produced than mature, further increases in yield could be achieved (Islam and Sedgley 1981). Tillers directly affect yield potential through the number of heads per unit area (Simmons et al. 1982). According to Hadjichristodoulou (1985) high yielding barley varieties in semi-arid environments were those with more tillers. However, Simmons et al. (1982) indicated the importance of number of grain-bearing tillers, not total tillers, in yield formation since nonbearing tillers decrease the $\mathrm{HI}$ and increase lodging susceptibility. Some tillering is considered necessary in order to compensate for differences in seeding rate (Major et al. 1992). When tillers were removed from barley plants, the HI was increased as well as grain mass, flower primordia number, stem diameter and leaf area (El Alaoui et al. 1988). This suggests that the uniculm plants could be more productive than conventional tillering ones. Nevertheless, in uniculm crops the stand density should be increased in order to achieve similar yields as conventional tillering stands, resulting in increased inter-plant competition. Uniculm crops are sensitive to competition and environmental stresses, especially since their ability to compensate yield components is limited (Balkema-Boostra and Mastebroek 1993). Intra-plant competition, however, is by definition absent since only one spike is formed per plant (Dofing 1996). Use of uniculm barley plants might be agronomically disadvantageous if the nonbearing tillers contribute substantial assimilate to the remaining stems. Thus, cultivars producing a limited number of tillers are recognised as having the greatest potential (El Alaoui et al. 1988). In northern conditions, spring cereals form zero to two head- or panicle-bearing tillers. These tillers are not, however, able to compensate for the grain yield main shoots produce (Peltonen-Sainio 1997). Increasing seeding rate up to $600-700$ seeds per $\mathrm{m}^{-2}$ results generally in a uniculm growth habit and increases the yield due to earlier canopy closure and higher peak LAI, but it increases inter-plant competition (Peltonen-Sainio and Järvinen 1994, 1995).

Spring cereal tillers develop from the axillary buds on the parent shoot located at the bottom of the internode of the parent phytomer. Only a few buds develop into a tiller and few of these produce heads while the others die (Evers et al. 2006). Hucl and Baker (1989) showed that the three first shoots, i.e., the main stem and first two tillers, accounted for two-thirds of the grain yield of the plant, and that the numbers of kernels per spike, kernel weight and grain yield per tiller decreased with tiller order. The main factors affecting tillering are environmental conditions, especially nutrients, water and light quantity, and population density of the canopy (Davis and Simmons 1994). Shoot number, and thus tiller number, of barley is mostly affected by row spacing and seeding rate (Simmons et al. 1982). The cessation of tillering is caused either by the formation of terminal spikelet on the apex of the parent shoot at the beginning of stem elongation (for a review see McMaster 1997) or by an integrated response to light conditions within the canopy (Evers et al. 2006).

The shift in tiller development pattern occurs early in development, implying that it is modulated photomorphogenically. Barley (Davis and Sim- 
Vol. 17 (2008): 289-306.

mons 1994) and wheat (Evers et al. 2006) respond to alterations in red:far red light signals at very early stages of development. The responses to these signals allow the plant to respond to neighbouring plants before experiencing shading. Suppression of tillering occurs more frequently for secondary and higher order tillers than in primary tillers which most often survive and bear grain (Davis and Simmons 1994). Tillering may cease at a fixed red:far red ratio, independent of phenological state and canopy density or substrate availability (Evers et al. 2006). Plants grown under altered light quality conditions throughout their development became acclimated and produced more tillers than plants that underwent a sudden decline in red:far red midway in the tillering phase (Davis and Simmons 1994). Lodging at grain filling period might launch this response of tillering, resulting in undesirable secondary tillering. It might be worth investigating what controls the red:far red signalling and whether that signalling could be manipulated to reduce the number of tillers both at the early stages of growth and after anthesis.

Tillers affect the leaf area of the plant and thus increase the water use of the crop. Although the unproductive tillers translocate some assimilate to the surviving stems, the losses in respiration and structural material and especially losses of water available for grain filling are high (Richards et al. 2002). According to Duggan et al. (2005), a reduction in tillering actually increases the assimilate supply for fertile tillers by decreasing the internal competition. In wheat, tillers and main stem leaves develop at the same rate (Mosaad et al. 1995, Schipper 1996). Thus, faster tillering is expected to accompany faster leaf appearance (Mosaad et al. 1995) and reduced tillering can at least partly be attributed to earlier flowering and reduced height of the plants. Also, the incidence of spikelet sterility is lower in low-tillering plants (Motzo et al. 2004). Utilisation of dwarfing genes changed the tillering pattern of spring cereals by reducing the number of tillers formed but increasing the number of head-bearing tillers, increasing the grain number per ear and greatly increasing the HI (Siddique et al. 1990a). The tiller inhibition gene (tin) was shown to inhibit the number of tillers in wheat and develop 'Gigas' characteristics such as large spikes and thick leaves and stems (Richards 1988). Even though the spike numbers of tin-expressing cereal lines is low, the grain yield is usually not significantly different from their isogenic counterparts, since these lines generally produce a greater number of kernels per spike and heavier kernels. The overall growth habit results in higher HI and reduced biomass production. However, the changes in architecture and yield components caused by tin depend strongly on the genetic background. The only disadvantages with tin-containing lines are that they cannot compensate for poor emergence and that the sowing rate should be increased slightly. These lines, however, have a yield advantage of $2 \%$ in Mediterranean conditions (Duggan et al. 2005). Thus, in the future we should aim for growing low-tillering spring cereal cultivars in Finland in order to be able to increase the HI of spring cereals as well as effective utilization of inputs.

\section{Stem reserves}

Lack of water at any of the growth stages between spike initiation and maturity causes severe losses in yield. The most sensitive stages are, however, meiosis of developing reproductive organs and, for dry matter accumulation, the cell division stage of endosperm and the most rapid growth stage of the grains (Ahmadi and Baker 2001). Remobilisation of carbohydrates stored pre-anthesis has a marked role during grain filling, especially when canopies suffer from abiotic and biotic stresses (Richards and Townley-Smith 1987). Despite the decrease in photosynthesis and in grain sucrose content, wheat grains continue to accumulate dry matter (Ahmadi and Baker 2001). Grain filling depends on substrate supplied by leaves and stem, which contribute $40-90 \%$ of the grain weight (for a review see Blum 1998). According to Davidson and Birch (1978), the cultivars able to utilise the stem-stored carbohydrates effectively during grain filling are more stable across environments.

There is debate about the sink or source limitation of yield. Grain weight of modern wheats is 


\section{AGRICULTURAL AND FOOD SCIENCE}

Mäkelä, P. et al. From ideotypes to cultivars in spring cereals

considered to be source limited. Kruk et al. (1997) stated that modern wheats have become source limited as a result of the selection of increasing sink demand without regard for source capacity. On the other hand, Slafer and Savin (1994) demonstrated a sink limitation of wheat yield. Oat and wheat grain size is non-uniform because up to five grains are produced per spikelet of which the proximal is the largest (Stoddard 1999, Doehlert et al. 2002) and this was attributed to reduced sink-strength and photoassimilate acquisition of higher order seeds (Doehlert et al. 2002). Modern wheat cultivars have the ability to utilise remobilisable assimilates produced before and after anthesis for grain filling to maintain grain weight (Pheloung and Siddique 1991). This is shown as a loss of dry weight in the upper two internodes (Davidson and Chevalier 1992), culms (Willenbrink et al. 1998) and the uppermost pulvinus (Virgona and Barlow 1991) simultaneously with an increase in grain weight. Usually the carbohydrates stored as fructans having a degree of polymerization between three and eight in stems are utilised as buffers of fluctuations in carbohydrate production (Kühbauch and Thome 1989). The polymerization degree of the fructans decreases rapidly under stress conditions (Virgona and Barlow 1991). Kühbauch and Thome (1989) noticed that even the number of endosperm cells was controlled by the ability of the plant to utilise the stem reserves, thus having a role in grain dry mass accumulation and final grain size. Therefore, it is important to pay even more attention to the use of stem reserves during grain filling.

\section{Water Use Efficiency}

The effect of water supply on yield is the same, approximately $6 \mathrm{~kg} \mathrm{~mm}^{-1}$, at moderate and low rainfall (Laing and Fischer 1977). Even the short periods of drought occurring in Finland restrict the formation of floral structures and increase abortion of kernels. Moreover, with climate change, drought periods will be more common and severe in Europe (Olesen and Bindi 2002) and the critical issue in Finland is whether they also become more frequent early in the growing season. Therefore, we should seriously take into consideration the traits which result in more stable yield formation, such as improved early vigour and water use efficiency, ability to utilise stem reserves, and dwarfing genes, which are linked to drought tolerance and environmental stresses over all. Early season drought affects the formation of flower structures and pollination and thus differs from the Mediterranean-type terminal drought that affects grain filling (Peltonen-Sainio and Peltonen 1995).

Water is also lost from yellowing leaves due to lack of stomatal control and from stems and leaf sheaths since these also have stomata (for a review, see Stanhill 1986, van den Boogaard et al. 1996). Water use efficiency can be affected by plant architecture. Even in similar height canopies, leaves can be more widely spaced on more erect stems, resulting in higher boundary layer conductance and higher leaf-to-air vapour-pressure difference (Siddique et al. 1990b). Górny (2001) stated that European barley cultivars were better adapted to low soil moisture than Mediterranean ones when evaluated as WUE and drought resistance. Moreover, older wheat and barley cultivars extracted more water than modern ones (Siddique et al. 1990b). Modern and early maturing cultivars used less water in the pre-anthesis period and more in the post-anthesis period, reducing the water deficit during grain filling and contributing to the larger grain size, enhancing suitability for short-season low-rainfall environments (Regan et al. 1997).

Carbon isotope discrimination $(\Delta)$, a measure of the ratio of stable carbon isotopes 13 and 12, is recognised as a good indicator of WUE. Photosynthetic machinery discriminates against ${ }^{13} \mathrm{C}$ if possible, i.e. when stomata are open (for a review see Condon et al. 2004). $\Delta$ indicates the genetic variation in transpiration efficiency of crops integrating the stomatal conductance and photosynthetic capacity with the dry matter laid down over time (Condon and Richards 1992). Condon et al. (1993) stated that early canopy growth was faster in high $\Delta$ genotypes. Both grain $\Delta$ and flag leaf $\Delta$ correlated positively with grain yield and harvest index. Thus, high $\Delta$ cultivars are able to maintain the carbon partitioning and translocation from stem reserves 
Vol. 17 (2008): 289-306.

to grains over a wide range of environments, i.e., have increased yield stability (Merah et al. 2001). According to Siddique et al. (1990b) improvement in WUE and thereby yield could be possible by increasing the HI, crop biomass and by paying more attention to cultivation techniques.

\section{Nitrogen Use Efficiency}

NUE is defined as grain production per unit of $\mathrm{N}$ available in the soil (Moll et al. 1982, van Sanford and MacKown 1986). When the definition is restricted to the ability of the plant to utilize applied $\mathrm{N}$ fertilizer (Tilman et al. 2002) it omits variation in $\mathrm{N}$ mineralised during crop growth and hence is more related to agronomic efficiency. Several studies have showed improved NUE in modern wheat (Austin et al. 1980, Slafer et al. 1990, Calderini et al. 1995, Ortiz-Monasterio et al. 1997, Foulkes et al. 1998, Reynolds et al. 1999) and oat cultivars (Muurinen et al. 2006) as well as improved agronomic efficiency of modern barley cultivars (Isfan 1990, Delogu et al. 1998, Abeledo et al. 2003) compared with their predecessors. However there are also indications of overall decreased NUE values in cereals in Western Europe (Hatfield and Prueger, 2004) and information that barley NUE may not have improved in northern growing conditions (Muurinen et al. 2006). NUE is a complex trait, determined by the ability of the plant first to extract soil $\mathrm{N}$ and then to convert the absorbed $\mathrm{N}$ into harvested grain yield (Moll et al. 1982, Ortiz-Monasterio et al. 1997).

\section{Nitrogen uptake}

Moll et al. (1982) speculated that N uptake efficiency was the component determining NUE as soil $\mathrm{N}$ supply increased. This is explained by $\mathrm{N}$ uptake exceeding the critical value of $\mathrm{N}$ content in crop dry matter (Lawlor et al. 2001, Lemaire and Millard 1999). However Ortiz-Monasterio et al. (1997) reported that $\mathrm{N}$ uptake is also an important component of NUE under low $\mathrm{N}$ conditions. $\mathrm{N}$ uptake efficiency in wheat accounted for most of the variation in NUE at low N availability (OrtizMonasterio et al. 1997, Le Gouis et al. 2000).

In northern growing conditions, spring cereals have a rapid growth rate during a very limited period, therefore the ability to take up large amounts of $\mathrm{N}$ between germination and maturing is essential (Løes 2003). Where $\mathrm{N}$ is supplied in a single dressing in spring, as in Nordic agricultural systems, soil nitrate level can drop during the growing season because of uptake by the crop, along with denitrification and leaching (Nielsen and Jensen 1986, Rekolainen et al. 1995, Paasonen-Kivekäs et al. 1999). Therefore developing grains could be filled mainly through redistribution of nitrogen from vegetative parts (Papakosta and Gagianas 1991, Bulman and Smith 1994). N can also be taken up from the soil during grain filling and this can contribute to protein yield and grain protein concentration (Cox et al. 1985). Longer duration of grain growth would require additional post-anthesis $\mathrm{N}$ uptake (Spiertz and de Vos 1983). Under Nordic growing conditions, half of the biomass is produced after the heading (Bertholdsson and Stoy 1995b, Muurinen et al. 2006) and this fact sets a high demand for late NUE.

Average reported uptake values by fertilized wheat and barley in temperate regions ranged from $20 \%$ to $100 \%$ (Gauer et al. 1992, Le Gouis et al. 2000, Sinebo et al. 2003, Noulas et al. 2004). Genetic variation for $\mathrm{N}$ uptake exists in cereals (Kelly et al. 1995, Singh and Arora 2001). There was hardly any correlation between total $\mathrm{N}$ uptake and year of cultivar release in wheat (Slafer et al. 1990, Calderini et al. 1995, Foulkes et al. 1998), although a positive trend was reported for six-row spring barley (Bulman et al. 1993) and oat (Wych and Stuthman 1983, Welch and Leggett 1997). Modern cultivars produce higher yields when grown with conventional applications of fertilizer (Evans and Fischer 1999) and the genetic gain has been especially large since 1960 (Austin 1999). However, it is less clear whether modern cultivars perform better in limited N conditions. Bertholdsson and Stoy (1995a) and Foulkes et al. (1998) found that the most recent cultivars were adapted to higher levels 


\section{AGRICULTURAL AND FOOD SCIENCE}

Mäkelä, P. et al. From ideotypes to cultivars in spring cereals

of $\mathrm{N}$ and took up relatively more $\mathrm{N}$ from fertilizer, whereas the older cultivars had a relatively large uptake of $\mathrm{N}$ mineralized from soil. Early vigorous growth has also been suggested as a major factor influencing $\mathrm{N}$ uptake in modern wheat lines (Liao et al. 2006). The higher $\mathrm{N}$ uptake of vigorous wheat genotypes has been associated with vigorous early root and shoot growth (Liao et al. 2004) and more abundant root branching increasing the root length density and the number of roots (Liao et al. 2006). Feil (1992) indicated that high biomass production was associated with greater efficiency in nutrient uptake, which could decrease the total NUE of modern cultivars. Since N concentration is higher in leaves than in stems and sheaths, $\mathrm{N}$ uptake may be more closely related to leafiness than to total shoot biomass (Feil 1997).

\section{Nitrogen partitioning}

N utilization efficiency (UTE), the ability to produce plant dry mass and thereafter grain yield from each unit of nutrient taken up, is expressed as the ratio of grain yield to total plant N (Moll et al. 1982, Cox et al. 1985). Genetic variation for UTE exists in cereals (Woodend et al. 1986, Papakosta 1994, Singh and Arora 2001) and is strongly related to $\mathrm{HI}$ and grain yield (Fischer and Wall 1976). Ortiz-Monasterio et al. (1997) subdivided UTE into HI and biomass production efficiency (BPE) affirming that HI was most associated with UTE. Therefore, UTE appears to be the nitrogen-use trait mainly affected by plant breeding (Slafer et al. 1990, Ortiz-Monasterio et al. 1997). HI has increased substantially through plant breeding whereas total shoot biomass has remained more or less unchanged (Austin et al. 1980, Bulman et al. 1993). Selection for higher HI may reduce the N storage capacity of the shoot (Feil 1997) and reduction in protein $\mathrm{N}$ has been associated with high UTE so the disadvantage of high UTE may be a reduced nutrient value of the grain (Calderini et al. 1995, Ortiz-Monasterio et al. 1997). Besides the better expression of UTE under either high soil N (Ortiz-Monasterio et al. 1997) or low soil N (Dhugga and Waines 1989), there are differences between cereal species in their NUE to UTE relationship. The association is especially strong for oat, regardless of N supply (Isfan 1990). Delogu et al. (1998) showed that in low N input environments, winter barley had higher UTE than winter wheat and UTE was also associated with higher $\mathrm{N}$ harvest index (NHI), which is expressed as the proportion of the total $\mathrm{N}$ yield contained in the grain at maturity (Cregan and Berkum 1984). This indicates retranslocation efficiency of $\mathrm{N}$ from vegetative plant parts, not including roots, to the grain. Many studies have indicated that $70 \%$ or more of the $\mathrm{N}$ harvested in grains is derived from $\mathrm{N}$ remobilized from senescing vegetative plant parts (Austin et al. 1977, Cox et al. 1985, Papakosta and Gagianas 1991). Values of NHI are strongly affected by $\mathrm{N}$ fertilization and climate (Feil 1997). Even though there are differences between species, cereal NHI values are usually high, even exceeding 80\% (Spiertz and de Vos 1983, Ugalde 1993, Feil 1997, Noulas et al. 2004). Therefore Cregan and Berkum (1984) suggested that the more detailed trait to measure the ability of a crop to remove $\mathrm{N}$ from the vegetative parts would be $\mathrm{N}$ remobilisation efficiency (NRE). $\mathrm{N}$ remobilisation efficiency is therefore estimated as the fraction of stored $\mathrm{N}$ at flowering that is not recovered in the vegetative parts at maturity (Barbottin et al. 2005). Improved understanding of plant $\mathrm{N}$ requirements and dynamics, particularly BPE and NRE from vegetative parts, is needed to determine better NUE among species and cultivars.

\section{Competition within canopies}

Competition can be divided into three different types (Fasoula 1990): 1. auto-competition, that of identical genotypes (e.g. clones, single cross hybrids, and pure lines) resulting in an even suppression of yield due to even sharing of resources, 2. allo-competition, that of different genotypes (e.g. populations, variety mixtures) leading to uneven yield suppression due to uneven sharing of resources, and 3. nil-competition, where each plant exploits the resources according to 
Vol. 17 (2008): 289-306.

its genetic potential without any effect from other plants. In canopies, single plants have to compete with each other. In crop mixtures, competition is most severe between different plant species. The most usual mixtures in Finland are of cultivars of a single species, either oat or barley, and binary mixtures of a cereal with pea (Pisum sativum L.), where barley shows the most plasticity of growth habit and wheat the least. According to Bebawi and Naylor (1978) growing crop mixtures results in higher yields, less susceptibility to lodging and diseases, superior quality and more stable yields from season to season. In intercropped wheat and field bean (Vicia faba L.) canopies the advantages are efficiency in nitrogen and land utilization as well as suppression of growth of weeds (Bulson et al. 1997). The quality demands by the food and feed industry, however, have limited the use of species or even cultivar mixtures. The differences in crop phenology of species restrict use of cereal mixtures, since the mechanical harvesting is complex when crops mature unevenly. In the future we should pay more attention to utilizing species and cultivar mixtures, since yield can be enhanced by increasing the number of species in crop mixtures in comparison to monocultures and binary mixtures (Tilman et al. 1996, Jolliffe and Wanjau 1999) and choices for late and early maturing cultivars have increased.

Cultivars in canopies compete with each other mostly for light, which is one of the major factors in determination of productivity (Donald 1963). Spikelet production increases with increasing light as well as spikelet number per ear after inflorescence initiation (Aspinall and Paleg 1973). Shading reduces tiller formation at the early growth stages and hence yield (Fisher 1975). Preanthesis shading reduces the number of grains per square meter by reducing especially the number of grains per spike, mainly from the basal spikelets, as well as number of spikes per square meter about 35\%. Decrease in number of spike-bearing tillers due to shading explained approximately $85 \%$ of the change in spikes per square meter (Slafer et al. 1994). However, grain yield at maturity is affected by shading also due to reduced cell expansion rates in filling grains, reducing grain weight. Modern cereal cultivars perform better under shading than old ones, probably due to their higher capacity to partition dry matter to spikes (Slafer et al. 1994). In northern conditions the seeding rates of spring cereals range from 450 to 600 seeds $\mathrm{m}^{-2}$ and whereas the competition within the canopy increases with increasing seeding rate, due to the nature of the growing period in northern latitudes, the grain yield has been higher at higher seeding rates in this range (Peltonen-Sainio and Järvinen 1994, 1995). Vigorous emergence results in more extensive root system and above-ground growth which also allows the earlier emerged plants to exploit the aerial and soil resources more extensively (Soetono and Donald 1980). Soetono and Donald (1980) stated that there can be three- to five-fold difference in grain yield produced by dominant or suppressed barley plants, due to early emergence or large seed size, higher growth rate based on early emergence, and competitive benefit based on both early emergence and high growth rate.

Weeds compete with crops for nutrients, water and light (Iqbal and Wright 1999). When crops effectively suppress the weeds, the need for use of herbicides decreases. The differences between cereal cultivars in their ability to suppress weeds are large, depending on the architecture and phenology of the cultivar (Christensen 1994, Lemerle et al. 1996a, 1996b). The response to competition begins before the plants are interfering with each other physically (Ballare 1999). According to Didon (2002), the emergence of crops is promoted in the presence of weed seeds. The cultivars which are tallest at the tillering stage and have highest initial growth rate possess the highest competitive advantage over weeds at the later stage of growth. On the other hand, incorporation of GA-sensitive dwarfing genes resulting in long coleoptiles in spring cereals would also result in increased ability of crops to compete with weeds after emergence due to more vigorous early growth and faster emergence (Rebetzke and Richards 2000). Bertholdsson (2005) showed that early vigour and allelopathy together explained $44-69 \%$ of observed genotypic variation in weed competition in barley. Pre-anthesis competition results in lower biomass accumulation and thus lower yield (Didon 2002). Around the time of anthesis, weed competition mostly reduces 


\section{AGRICULTURAL AND FOOD SCIENCE}

Mäkelä, P. et al. From ideotypes to cultivars in spring cereals

number of ears per plant and number of grains per ear due to decreased tiller initiation and increased tiller mortality. After anthesis, the weed competition has no significant role for crop yield (Iqbal and Wright 1999). As the growth habit of barley and wheat differ from each other, the important traits of competitive canopies are also different. For wheat, competitive canopies should have horizontal leaves (Huel and Hucl 1996, Seavers and Wright 1999), whereas for barley they should have vertical leaves and numerous tillers (Didon 2002). With rice, the greater specific leaf area, resulting in wider leaves, has been used in an attempt to increase the weed competitiveness successfully (Dingkuhn et al. 1999). Thus, at the early stages vigorously developing cultivars have the advantage over the weeds and possibly possess potential for further decrease in the use of herbicides. However, the breeding in the last decade or two has focused on decreasing the canopy height to increase the HI and decrease the lodging. To increase the competitive ability without increased risk of lodging and losses of gains achieved in HI, we should aim for fast germinating, vigorously growing cultivars which have rather long first internodes but after tillering stage short internodes. The role of roots in competition with weeds remains to be investigated.

\section{Conclusions}

This review summarizes traits that can be considered particularly relevant for ideotype of spring cereals grown in northern conditions. It also takes into account farmers' perspective in the sense that today, but increasingly in the future, better resource use efficiency is particularly important. Early vigour of a spring cereal crop has a major role as the yield potential is developed at the early stages of crop growth. The target in future should be in increasing the leaf area at early stages of growth, thus increasing the resource capture. That could be achieved by using large seed material (especially seeds with large embryos), paying attention to faster rate of early development as well as selecting for long coleoptiles. As a result the canopies would be emerging quickly as well as develop and cover the ground evenly. High early vigour is also connected to increased water use efficiency and thus, drought resistance of canopies. Introduction of appropriate dwarfing genes into cultivars grown in Northern latitudes could result in reduced stature, lodging resistant crops. It would be useful to select for one or two vigorously growing tillers that are able to bear a head or panicle, since development of several tillers which will later die would increase the competition for assimilates in the plant at the most critical phase of yield determination. Use of dwarfing genes has also increased the HI of spring cereals in other parts of world due to the fact that dwarf varieties have increased ear:stem ratios, invest more dry matter in floret and spikelet formation, have higher floret survival and longer grain filling period than tall varieties. One important feature for conditions of Northen latitudes would be increased ability to retranslocate the carbohydrates stored in stems. This would ensure the dry matter accumulation in grains even when photosynthesis is restricted, e.g., on cloudy days or due to pathogens, drought or waterlogging. All of these traits would also increase the competitive ability of the plant against weeds as well as competition within the crop canopy and their role will likely be emphasised with climate change.

Acknowledgements: This article is dedicated to emer. prof. Eero Varis to honour his enthusiasm towards crop science, and the interest and encouragement he has shown us. We are grateful for Dr. Frederick Stoddard for his constructive comments and linguistic revision of the manuscript.

\section{References}

Abeledo, L.G., Calderini, D.F. \& Slafer, G.A. 2003. Genetic improvement of yield responsiveness to nitrogen fertilization and its physiological determinants in barley. Euphytica 133: 291-298.

Adams, M.W. 1982. Plant architecture and yield breeding. lowa State Journal of Research 56: 225-254.

Ahmadi, A. \& Baker, D.A. 2001. The effect of water stress on grain filling processes in wheat. Journal of Agricultural Science 136: 257-269. 
Vol. 17 (2008): 289-306.

Allan, R.E. 1986. Agronomic comparisons among wheat lines nearly isogenic for three reduced-height genes. Crop Science 26: 707-710.

Aparicio, N., Villegas, D., Araus, J.L., Blanco, R. \& Royo, C. 2002. Seedling development and biomass as affected by seed size and morphology in durum wheat. Journal of Agricultural Science 139: 143-150.

Aspinall, D. \& Paleg, L.G. 1963. Effects of day length and light intensity on growth of barley. I. Growth and development of the apex with a fluorescent light source. Botanical Gazette 124: 429-437.

Austin, R.B. 1988. A different ideotype for each environment? In: Jorna, M.L. \& Slootmaker, L.A.J. (eds.) Cereal Breeding Related to Integrated Cereal Production. Proceedings of the Conference of the Cereal Section of EUCARPIA. 24-26 February 1988. Pudoc Wageningen. pp: 47-61.

Austin, R.B. 1999. Yield of wheat in the United Kingdom: Recent advances and prospects. Crop Science 39: 1604-1610.

Austin, R.B., Bingham, J., Blackwell, R.D., Evans, L.T., Ford, M.A., Morgan, C.L. \& Taylor, M. 1980. Genetic improvements in winter wheat yields since 1900 and associated physiological changes. Journal of Agricultural Science 94: 675-689.

Austin, R.B., Ford, M.A., Edrich, J.A. \& Blackwell, R.D. 1977. The nitrogen economy of winter wheat. Journal of Agricultural Science 88: 159-167.

Balkema-Boomstra, A.G. \& Mastebroek, H.D. 1993. The grain yield of uniculm barley (Hordeum vulgare L.) in two contrasting environments. Euphytica 66: 103-110.

Ballare, C.L. 1999. Keeping up with the neighbours: phytochrome sensing and other signalling mechanisms. Trends in Plant Sciences 4: 97-102.

Barbottin, A., Lecomte, C., Bouchard, C. \& Jeuffroy, M.H. 2005. Nitrogen remobilization during grain filling in wheat: genotypic and environmental effects. Crop Science 45: 1141-1150.

Bebawi, F.F. \& Naylor, R.E.L. 1978. Yield performance of mixtures of oats and barley. New Phytologist 81: 705-710.

Berry, P.M., Sylvester-Bradley, R. \& Berry, S. 2007. Ideotype for lodging-resistant wheat. Euphytica 154: 165-179.

Bertholdsson, N.O. 1990. The influence of the pea plant ideotype on seed protein content and seed yield. Journal of Agronomy and Crop Science 164: 54-67.

Bertholdsson, N.O. 2005. Early vigour and allelopathy - two useful traits for enhanced barley and wheat competitiveness against weeds. Weed Research 45: 94-102.

Bertholdsson, N.O. \& Stoy, V. 1995a. Accumulation of biomass and nitrogen during plant growth in highly diverging genotypes of winter wheat. Journal of Agronomy and Crop Science 175: 167-182.

Bertholdsson, N.O. \& Stoy, V. 1995b. Yields of dry matter and nitrogen in highly diverging genotypes of winter wheat in relation to $\mathrm{N}$-uptake and $\mathrm{N}$-utilization. Journal of Agronomy and Crop Science 175: 285-295.

Bishop, D.L. \& Bugbee, B.G. 1998. Photosynthetic capacity and dry mass partitioning in dwarf and semi-dwarf wheat (Triticum aestivum L.). Journal of Plant Physiology 153: 558-565.
Blum, A. 1998. Improving wheat grain filling under stress by stem reserve mobilisation. Euphytica 100: 77-83.

Borrell, A.K., Incoll, L.D. \& Dalling, M.J. 1991. The influence of the $R h t_{1}$ and $R h t_{2}$ alleles on the growth of wheat stems and ears. Annals of Botany 67: 103-110.

Botwright, T.L., Condon, A.G., Rebetzke, G.J. \& Richards, R.A. 2002. Field evaluation of early vigour for genetic improvement of grain yield in wheat. Australian Journal of Agricultural Research 53: 1137-1145.

Botwright, T.L., Rebetzke, G.J., Condon, A.G. \& Richards, R.A. 2005. Influence of the gibberellin-sensitive Rht8 dwarfing gene on leaf epidermal cell dimensions and early vigour in wheat (Triticum aestivum L.). Annals of Botany 95: 631-639.

Bulman, P., Mather, D.E. \& Smith, D.L. 1993. Genetic improvement of spring barley cultivars grown in eastern Canada from 1910 to 1988. Euphytica 71: 35-48.

Bulman, P. \& Smith, D.L. 1994. Post-harvest uptake, retranslocation, and partitioning in spring barley. Crop Science 34: 977-984.

Bulson, H.A.J., Snaydon, R.W. \& Stopes, C.E. 1997. Effects of plant density on intercropped wheat and field beans in an organic farming system. Journal of Agricultural Science 128: 59-71.

Bumb, B.L. 1995. World nitrogen supply and demand: an overview. In: Bacon, P.E. (ed.). Nitrogen Fertilization in the Environment. Marcel Dekker, Inc., New York. Pp: $1-35$.

Calderini, D.F., Torres-León, S. \& Slafer G.A. 1995. Consequences of wheat breeding on nitrogen and phosphorus yield, grain nitrogen and phosphorus concentration and associated traits. Annals of Botany 76: 315-322.

Calderini, D.F., Miralles, D.J. \& Sadras, V.O. 1996. Appearance and growth of individual leaves as affected by semidwarfism in isogenic lines of wheat. Annals of Botany 77: 583-589.

Chen, S.G., Ceulemans, R \& Impens, I. 1994. Is there a light regime determined tree ideotype? Journal of Theoretical Biology 169: 153-161.

Christensen, S. 1994. Crop weed competition and herbicide performance in cereal species and varieties. Weed Research 34: 29-36.

Clark, R.B. 1990. Physiology of cereals for mineral nutrient uptake, use and efficiency. In: Baligar, V.C. \& Duncan, R.R. (eds.). Crops as Enhancers of Nutrient Use. Academic Press, San Diego. pp: 131-209.

Condon, A.G. \& Richards, R.A. 1992. Broad sense heritability and genotype $x$ environment interaction for carbon isotope discrimination in field-grown wheat. Australian Journal of Agricultural Research 43: 921-934.

Condon, A.G., Richards, R.A. \& Farquhar, G.D. 1993. Relationships between carbon isotope discrimination, water use efficiency and transpiration efficiency for dryland wheat. Australian Journal of Agricultural Research 44: 1693-1711.

Condon, A.G., Richards, R.A., Rebetzke, G.J. \& Farquhar, G.D. 2004. Breeding for high water-use efficiency. Journal of Experimental Botany 55: 2447-2460.

Cox, M.C., Qualset, C.O. \& Rains, D.W. 1985. Genetic variation fro nitrogen assimilation and translocation in wheat: II. Nitrogen assimilation in relation to grain yield and protein. Crop Science 25: 435-440. 


\section{AGRICULTURAL AND FOOD SCIENCE}

Mäkelä, P. et al. From ideotypes to cultivars in spring cereals

Cregan, P.B. \& Berkum, P. 1984. Genetics of nitrogen metabolism and physiological/biochemical selection for increased grain crop productivity. Theoretical and Applied Genetics 67: 97-111.

Davidson, D.J. \& Chevalier, P.M. 1992. Storage remobilization of water-soluble carbohydrates in stems of spring wheat. Crop Science 32: 186-190.

Davidson, J.L. \& Birch, J.W. 1978. Responses of a standard Australian and a Mexican wheat to temperature and water stress. Australian Journal of Agricultural Research 29: 1091-1106.

Davis, M.H. \& Simmons, S.R. 1994. Tillering response of barley to shifts in light quality caused by neighbouring plants. Crop Science 34: 1604-1610.

Delogu, G., Cattivelli, L., Pecchioni, N., de Falcis, D., Maggiore, T. \& Stanca, A.M. 1998. Uptake and agronomic efficiency in winter barley and winter wheat. European Journal of Agronomy 9: 11-20.

de Rocquigny, P.J., Entz, M.H., Gentile, R.M. \& Duguid, S.D. 2004. Yield physiology of a semidwarf and tall oat cultivar. Crop Science 44: 2116-2122.

Dhugga, K.S. \& Waines, J.G. 1989. Analysis of nitrogen accumulation and use in bread and durum wheat. Crop Science 29: 1232-1239.

Didon, U.M.E. 2002. Variation between barley cultivars in early response to weed competition. Journal of Agronomy and Crop Science 188: 176-184.

Dingkuhn, M., Johnson, D.E., Sow, A. \& Audebert, A.Y. 1999. Relationship between upland rice canopy characteristics and weed competitiveness. Field Crops Research 61, 71-95.

Doehlert, D.C., McMullen, M.S. \& Riveland, N.R. 2002. Sources of variation in oat kernel size. Cereal Chemistry 79: 528-534.

Dofing, S.M. 1992. Growth, phenology, and yield components of barley and wheat grown in Alaska. Canadian Journal of Plant Science 72: 1227-1230.

Dofing, S.M. 1996. Near-isogenic analysis of uniculm and conventional-tillering barley lines. Crop Science 36: 1523-1526.

Donald, C.M. 1963. Competition among crop and pasture plants. Advances in Agronomy 15: 1-118.

Donald, C.M. 1968. The breeding of crop ideotypes. Euphytica 17: 385-403.

Duggan, B.L., Richards, R.A., van Herwaarden, A.F. \& Fettel, N.A. 2005. Agronomic evaluation of a tiller inhibition gene (tin) in wheat. I. Effect on yield, yield components, and grain protein. Australian Journal of Agricultural Research 56: 169-178.

El Alaoui, A.C., Simmons, S.R. \& Crookston, R.K. 1988. Effects of tiller removal on spring barley. Crop Science 28: 305-307.

Ellis, M.H., Rebetzke, G.J., Chandler, P., Bonnet, D., Spielmeyer, W. \& Richards, R.A. 2004. The effect of different height reducing genes on the early growth of wheat. Functional Plant Biology 31: 583-589.

Evers, J.B., de Vos, J., Andrieu, B. \& Struik, P.C. 2006. Cessation of tillering in spring wheat in relation to light interception and red:far red ratio. Annals of Botany 97: 649-658.

Evans, L.T. \& Fisher, R.A. 1999. Yield potential: Its definition, measurement and significance. Crop Science 39: 1544-1551.
Fasoula, D.A. 1990. Correlations between auto-, allo-, and nil-competition and their implications in plant breeding. Euphytica 50: 57-62.

Feil, B. 1992. Breeding progress in small grain cereals - a comparison of old and modern cultivars. Plant Breeding 108: 1-11.

Feil, B. 1997. The inverse yield-protein relationship in cereals: possibilities and limitation for genetically improving the grain protein yield. Trends in Agronomy 1: 103-119.

Fisher, R.A. 1975. Yield potential in dwarf spring wheat and the effect of shading. Crop Science 15: 607-613.

Fisher, R.A \& Wall, P.C. 1976. Wheat breeding in Mexico and yield increases. Journal of Australian Industrial Agricultural Science 42: 139-148.

Foulkes, M.J., Sylvester-Bradley, R. \& Scott, R. 1998. Evidence for differences between winter wheat cultivars in acquisition of soil mineral nitrogen and uptake and utilization of applied fertilizer nitrogen. Journal of Agricultural Science 130: 29-44.

Gauer, L.E., Grant C.A., Gehl, D.T. \& Bailey, L.D. 1992. Effects of nitrogen fertilization on grain protein content, nitrogen uptake and nitrogen use efficiency of six spring wheat (Triticum aesticum L.) cultivars in relation to estimated moisture supply. Canadian Journal of Plant Science 72: 235-241.

Giunta, F., Motzo, R. \& Pruneddu, G. 2007. Trends since 1900 in the yield potential of Italian-bred durum wheat cultivars. European Journal of Agronomy 27: 12-24.

Gooding, S., Botwright Acuña, T.L., Fox, P.N. \& Wade, L.J. 2006. Emergence, stand establishment and vigour of deep-sown Australian and CIMMYT wheats. Australian Journal of Experimental Agriculture 46: 1167-1175.

Górny, A.G. 2001. Variation in utilization efficiency and tolerance to reduced water and nitrogen supply among wild and cultivated barleys. Euphytica 117: 59-66.

Gregory, P.J. \& Atwell, B.J. 1991. The fate of carbon in pulse-labelled crops of barley and wheat. Plant and Soil 136: 205-213.

Hadjichristodoulou, A. 1985. The stability of the number of tillers of barley varieties and its relation with consistency of performance under semi-arid conditions. Euphytica 24: 641-649.

Hatfield, J.L. \& Prueger, J.H. 2004. Nitrogen over-use, under-use, and efficiency. In (T. Fischer, ed.) New Direction for a Diverse Planet. Proc. $4^{\text {th }}$ International Crop ScienceCongress, Brisbane, Australia. 26 Sept. -1 Oct. 2004. Available at www.cropscience.org.au. The Regional Inst. Ltd.

Hucl, P. \& Baker, R.J. 1989. Tiller phenology and yield of spring wheat in a semiarid environment. Crop Science 29: 631-635.

Huel, D.G. \& Hucl P. 1996. Genotypic variation for competitive ability in spring wheat. Plant Breeding 115: 325-329.

Isfan, D. 1990. Genotypic variability for physiological efficiency index of nitrogen in oats. Plant and Soil 154: 53-59.

Iqbal, J. \& Wright, D. 1999. Effects of weed competition on flag leaf photosynthesis and grain yield of spring wheat. Journal of Agricultural Science 132: 23-30.

Islam, T.M.T. \& Sedgley, R.H. 1981. Evidence for a 'uniculm effect' in spring wheat (Triticum aestivum L.) in a mediterranean environment. Euphytica 30: 277-282. 
Vol. 17 (2008): 289-306.

Jolliffe, P.A. \& Wanjau, F.M. 1999. Competition and productivity in crop mixtures: some properties of productive intercrops. Journal of Agricultural Science 132: 425-435.

Kelly, J.T., Bacon, R.K. \& Wells, B.R. 1995. Genetic variability in nitrogen utilization at four growth stages in soft red winter wheat. Journal of Plant Nutrition 18: 969-982.

Kruk, B.C., Calderini, D.F. \& Slafer, G.A. 1997. Grain weight in wheat cultivars released from 1920 to 1990 as affected by post-anthesis defoliation. Journal of Agricultural Science 128: 273-281.

Kühbauch, W. \& Thome, U. 1989. Nonstructural carbohydrates of wheat stems as influenced by sink-source manipulations. Journal of Plant Physiology 134: 243-250.

Lafond, G.P. \& Baker, R.J. 1986. Effects of genotype and seed size on speed of emergence and seedling vigour in nine spring wheat cultivars. Crop Science 26: 341-346.

Laing, D.R. \& Fischer, R.A. 1977. Adaptation of semidwarf wheat cultivars to rainfed conditions. Euphytica 26: $129-139$.

Langton, F.A. 1991. Selection for production traits in flower crops. In: Harding, J., Singh, F. \& Mol, J.N.M. (eds.). Genetics and Breeding of Ornamental Species. Kluwer Academic Publishers, Dordrecht. Pp: 135-155.

Larsson, S. \& Górny A.G. 1988. Grain yield and drought resistance indices of oat cultivars in field rain shelter and laboratory experiments. Journal of Agronomy and Crop Science 161: 277-286.

Lawlor, D.W., Lemaire, G. \& Gastal, F. 2001. Nitrogen, plant growth and crop yield. In (P.J. Lea \& J.F. Morot Gaundry, eds.) Plant Nitrogen. Springer Verlag, Berlin. Pp: 343-367.

Le Gouis, J., Béghin, D., Heumez, E. \& Pluchard, P. 2000. Genetic differences for nitrogen uptake and nitrogen utilisation efficiency in winter wheat. European Journal of Agronomy 12: 163-173.

Lemaire, G. \& Millard, P. 1999. An ecophysiological approach to modelling resource fluxes in competing plants. Journal of Experimental Botany 50: 15-28.

Lemerle, D., Verbeek, B., Cousens, R.D. \& Coombes, E. 1996a. The potential for selecting wheat varieties strongly competitive against weeds. Weed Science 36: 505-514.

Lemerle, D., Verbeek, B., Cousens R.D. \& Coombes E. 1996b. Interaction between wheat (Triticum aestivum) and Diclofop to reduce the cost of annual ryegrass ( $\mathrm{LO}$ lium rigidum) control. Weed Science 44: 634-639.

Liang, Y.L. \& Richards, R.A. 1994. Coleoptile tiller development is associated with fast early vigour in wheat. Euphytica 80: 119-124.

Liao, M.T., Fillery, I.R.P. \& Palta, J.A. 2004. Early vigorous growth is a major factor influencing nitrogen uptake in wheat. Functional Plant Biology 31: 121-129.

Liao, M.T., Palta, J.A. \& Fillery, I.R.P. 2006. Root characteristics of vigorous wheat improve early nitrogen uptake. Australian Journal of Agricultural Research 57: 1097-1107.

Løes, A.K. 2003. Studies of the availability of soil phosphorus $(P)$ and potassium $(K)$ in organic farming systems, and of plant adaptations to low $\mathrm{P}$ - and K-availability. Ph.D. dissertation 29. Agricultural University of Norway, Ås.
Lopez-Castaneda, C., Richards, R.A., Farquhar, G.D. \& Williamson, R.E. 1996. Seed and seedling characteristics contributing to variation in early vigour among temperate cereals. Crop Science 1996: 1257-1266.

MacKey, J. 1988. Shoot:root interrelations in oats. In (B. Mattsson and R. Lyhagen, eds.) Proceedings of the 3rd International Oat Conference, Svalöv, Sweden. Pp: 340-344.

Major, D.J., Janzen, H.H., Sadasivah, R.S. \& Carefoot, J.M. 1992. Morphological characteristics of wheat associated with high productivity. Canadian Journal of Plant Science 72: 689-698.

Mäkelä, P., Muurinen, S. \& Peltonen-Sainio, P. 2004. Alterations in canopy architecture among dwarf, semidwarf and tall oat lines grown under northern conditions. Agricultural and Food Science 13: 170-185.

Mäkelä, P., Väärälä, L. \& Peltonen-Sainio, P. 1996. Agronomic comparison of Minnesota-adapted dwarf oat with semi-dwarf, intermediate, and tall oat lines adapted to northern growing conditions. Canadian Journal of Plant Science 76: 727-734.

McMaster, G.S. 1997. Phenology, development, and growth of the wheat (Triticum aestivum L.) shoot apex: A review. Advances in Agronomy 59: 62-118.

Merah, O., Deleens, E., Souyris, I. \& Monneveux, P. 2001. Ash content might predict carbon isotope discrimination and grain yield in durum wheat. New Phytologist 149: 275-282.

Milach, S.C.K. \& Federizzi, L.C. 2001. Dwarfing genes in plant improvement. Advances in Agronomy 73: 35-63.

Milach, S.C.K., Rines, H.W. \& Phillips, R.L. 1998. Plant height components and gibberellic acid response of oat dwarf lines. Crop Science 42: 1147-1154.

Miralles, D.J. \& Slafer, G.A. 1997. Radiation interception and radiation use efficiency of near-isogenic wheat lines with different height. Euphytica 97: 201-208.

Mock, J.J. \& Pearce, R.B. 1975. An ideotype of maize. Euphytica 24: 613-623.

Moll, R.H., Kamprath, E.J. \& Jackson, W.A. 1982. Analysis and interpretation of factors which contribute to efficiency of nitrogen utilization. Agronomy Journal 74: 562-564.

Mosaad, M.G., Ortiz-Ferrara, G. \& Mahalakshmi, V. 1995. Tiller development and contribution to yield under different moisture regimes in two Triticum species. Journal of Agronomy and Crop Science 174: 173-180.

Motzo, R., Giunta, F. \& Deidda, M. 2004. Expression of a tiller inhibitory gene in the progenies of interspecific crosses Triticum aestivum L. x T. turgidum subsp. durum. Field Crops Research 85: 15-20.

Muurinen, S., Slafer, G.S. \& Peltonen-Sainio, P. 2006. Breeding effects on nitrogen use efficiency of spring cereals under northern conditions. Crop Science 46: 561-568.

Nielsen, N.E. \& Jensen, H.E. 1986. The course of nitrogen uptake by spring barley from soil and fertilizer nitrogen. Plant and Soil 91: 391-395.

Noulas, C., Stamp, P. Soldati, A. \& Liedgens, M. 2004. Nitrogen use efficiency of spring wheat genotypes under field and lysimeter conditions. Journal of Agronomy and Crop Science 190: 111-118.

Öfversten, J., Jauhiainen, L. \& Kangas, A. 2004. Contribution of new varieties to cereal yields in Finland be- 


\section{AGRICULTURAL AND FOOD SCIENCE}

Mäkelä, P. et al. From ideotypes to cultivars in spring cereals

tween 1973 and 2003. Journal of Agricultural Science 142: $281-287$.

Olesen, J.E. \& Bindi, M. 2002. Consequences of climate change for European agricultural productivity, land use and policy. European Journal of Agronomy 16: 239-262.

Ortiz-Monasterio, J.L., Sayre, K.D., Rajaram, S. \& McMahon, M. 1997. Genetic progress in wheat yield and nitrogen use efficiency under four nitrogen rates. Crop Science 37: 898-904.

Paasonen-Kivekäs, M., Koivusalo, H., Karvonen, T. Vakkilainen, P. \& Virtanen. J. 1999. Nitrogen transport via surface and subsurface flow in an agricultural field. In: Heathwaite, L. (ed.). Impact of Land-Use Change on Nutrient Loads from Diffused Sources. Proceedings of IUGG 99 Symposium HS3, Birmingham, July 1999. IAHS Publication no. 257: 163-169.

Papakosta, D.K. 1994. Analysis of wheat cultivar in grain yield, grain nitrogen yield and nitrogen utilization efficiency. Journal of Agronomy and Crop Science 172: 305-316.

Papakosta, D.K. \& Gagianas, A.A. 1991. Nitrogen and dry matter accumulation, remobilization and losses for Mediterranean wheat during grain filling. Agronomy Journal 83: 864-870.

Passioura, J. 1983. Roots and drought resistance. Agricultural Water Management 7: 265-280.

Peltonen-Sainio, P. 1991. Productive ideotype for northern growing conditions. Euphytica 54: 27-32.

Peltonen-Sainio, P. 1993. Contribution of enhanced growth rate and associated physiological changes to yield formation of oats. Field Crops Research 33: 269-281.

Peltonen-Sainio, P. 1994. Growth duration and aboveground dry-matter partitioning in oats. Agricultural Science in Finland 3: 195-198.

Peltonen-Sainio, P. 1996. Sowing time effects on growth duration and formation and realization of yield potential of oat in Northern growing conditions. Cereal Research Communications 24: 223-229.

Peltonen-Sainio, P. 1997. Leaf area duration of oat at high latitudes. Journal of Agronomy and Crop Science 178: 149-155.

Peltonen-Sainio, P. \& Järvinen, P. 1994. Seeding rate effects on tillering, grain yield, and yield components of oat at high latitude. Field Crops Research 40: 49-56.

Peltonen-Sainio, P. \& Järvinen, P. 1995. Effects of seeding rate on growth duration and accumulation and partitioning of dry matter in oats. Journal of Agronomy and Crop Science 173: 145-159.

Peltonen-Sainio, P. \& Peltonen, J. 1995. Floret set and abortion in oat and wheat under high and low nitrogen regimes. European Journal of Agronomy 4: 253-262.

Pheloung, P.C. \& Siddique, K.H.M. 1991. Contribution of stem dry matter to grain yield in wheat cultivars. Australian Journal of Plant Physiology 18: 53-64.

Pyökkö, V.T. \& Pulkkinen, P.O. 1990. Characteristics of normal-crowned and pendula spruce (Picea abies (L.) Karst.) examined with reference to the definition of a crop tree ideotype. Tree Physiology 7: 201-207.

Rasmusson, D.C. 1987. An evaluation of ideotype breeding. Crop Science 27: 1140-1146.

Rebetzke, G.J. \& Richards, R.A. 2000. Gibberellic acidsensitive dwarfing genes reduce plant height to increase kernel number and grain yield of wheat. Australian Journal of Agricultural Research 51: 235-245.

Rebetzke, G.J., Richards, R.A., Fischer, V.M. \& Mickelson, B.J. 1999. Breeding long coleoptile, reduced height wheats. Euphytica 106: 159-168.

Regan, K.L., Siddique, K.H.M., Tennant, D. \& Abrecht, D.G. 1997. Grain yield and water use efficiency of early maturing wheat in low rainfall environments. Australian Journal of Agricultural Research 48: 595-603.

Rekolainen, S., Pitkänen, H., Bleeker, A. \& Felix, S. 1995. Nitrogen and phosphorus fluxes from Finnish agricultural areas to the Baltic Sea. Nordic Hydrology 26: 55-72.

Reynolds, M.P., Rajaram, S. \& Sayre, K.D. 1999. Physiological and genetic changes of irrigated wheat in the postgreen revolution period and approaches for meeting projected global demand. Crop Science 39: 1611-1621.

Richards, R.A. 1988. A tiller inhibition gene in wheat and its effect on plant growth. Australian Journal of Agricultural Research 39: 749-757.

Richards, R.A. 1992a. The effect of dwarfing genes in spring wheat in dry environments. I. Agronomic characters. Australian Journal of Agricultural Research 43: 517-527.

Richards, R.A. 1992b. The effect of dwarfing genes in spring wheat in dry environments. II. Growth, water use and water-use efficiency. Australian Journal of Agricultural Research 43: 529-539.

Richards, R.A. \& Lukacs, Z. 2002. Seedling vigour - sources of variation for genetic and agronomic improvement. Australian Journal of Agricultural Research 53: 41-50.

Richards, R.A., Rebetzke, G.J., Condon, A.G. \& van Herwaarden, A.F. 2002. Breeding opportunities for increasing the efficiency of water use and crop yield in temperate cereals. Crop Science 42: 111-121.

Richards, R.A. \& Townley-Smith, T.F. 1987. Variation in leaf area development and its effect on water use, yield and harvest index of droughted wheat. Australian Journal of Agricultural Research 38: 983-992.

Sadras, V.O. 2005. A quantitative top-down view of interactions between stresses: Theory and analysis of nitrogen-water co-limitation in Mediterranean agro-ecosystems. Australian Journal of Agricultural Research 56: 1151-1157.

Schipper, J. 1996. Relation between pattern of development of wheat seedlings and growth rate of leaves, tillers and roots. Journal of Agronomy and Crop Science 176: 199-211.

Seavers, G.P. \& Wright, K.J. 1999. Crop canopy development and structure influence weed suppression. Weed Research 39: 319-328.

Sedgley, R.H. \& Belford, R.K. 1991. Preface: Ideotypes and physiology: tailoring plants for increased production. Field Crops Research 26: 89-92.

Siddique, K.H.M., Belford, R.K. \& Tennant, D. 1990a. Root:shoot ratios of old and modern, tall and semidwarf wheats in mediterranean environment. Plant and Soil 121: 89-98.

Siddique, K.H.M., Tennant, D., Perry, M.W. \& Belford, R.K. 1990b. Water use and water use efficiency of old and modern wheat cultivars in a Mediterranean-type environments. Australian Journal of Agricultural Research 41: 431-447. 
Vol. 17 (2008): 289-306.

Simmons, S.R., Rasmusson, D.C. \& Wiersma, J.V. 1982. Tillering in barley: genotype, row spacing, and seeding rate effects. Crop Science 22: 801-805.

Sinebo, W., Gretzmacher, R. \& Edelbauer, A. 2003. Genotypic variation for nitrogen use efficiency in Ethiopian barley. Field Crops Research 85: 43-60.

Singh, V.P. \& Arora, A. 2001. Intraspecific variation in nitrogen uptake and nitrogen utilization efficiency in wheat (Triticum aestivum L.). Journal of Agronomy and Crop Science 186: 239-244.

Singh, R.P., Huerta-Espino, J., Rajaram, S. \& Crossa, J. 2001. Grain yield and other traits of tall and dwarf isolines of modern bread and durum wheats. Euphytica 119: 241-244.

Slafer, G.A., Andrade, F.H. \& Feingold, S.E. 1990. Genetic improvement of bread wheat (Triticum aestivum L.) in Argentina: Relationships between nitrogen and dry matter. Euphytica 50: 63-71.

Slafer, G.A., Araus, J.L., Royo, C. \& Garcia Del Moral, L.F. 2005. Promising eco-physiological traits for the genetic improvement of cereal yields in Mediterranean environments. Annals of Botany 146: 61-70.

Slafer, G.A., Calderini, D.F., Miralles, D.J. \& Dreccer, M.F. 1994. Preanthesis shading effects on the number of grains of three bread wheat cultivars of different potential number of grains. Field Crops Research 36: 31-39.

Slafer, G.A. \& Peltonen-Sainio, P. 2001. Yield trends of temperate cereals in high latitude countries from 1940 to 1998. Agricultural and Food Science Finland 10: 121-131.

Slafer, G.A. \& Savin, R. 1994. Source-sink relationships and grain mass at different positions within the spike in wheat. Field Crops Research 37: 39-49.

Sloane, D.H.G., Gill, G.S. \& McDonald, G.K. 2004. The impact of agronomic manipulation of early vigour in wheat on growth and yield in South Australia. Australian Journal of Agricultural Research 55: 645-654.

Soetono \& Donald, C.M. 1980. Emergence, growth and dominance in drilled and square-planted barley crops. Australian Journal of Agricultural Research 31: 455-470.

Spiertz, J.H.J. \& de Vos, N.M. 1983. Agronomy and physiological aspects of the role of nitrogen in yield formation of cereals. Plant and Soil 75: 379-391.

Stanhill, G. 1986. Water Use Efficiency. Advances in Agronomy 39: 53-85.

Stoddard, F.L. 1999. Variation in grain size, grain nitrogen and starch B-granule content in wheat heads. Cereal Chemistry 76: 139-144
Tilman, D., Wedin, D. \& Knops, J. 1996. Productivity and sustainability influenced by biodiversity in grassland ecosystems. Nature 379: 718-729.

Tilman, D., Cassman, K.G., Matson, P.A., Naylor, R. \& Polasky, S. 2002. Agricultural sustainability and intensive production practices. Nature 418: 671-677.

Turk, M.A. \& Tawaha, A.M. 2002. Seed germination and seedling growth of two barley cultivars under moisture stress. Research on Crops 3: 467-472.

van den Boogaard, R., Veneklaas, E.J. \& Lambers, H. 1996. The association of biomass allocation with growth and water use efficiency of two Triticum aestivum cultivars. Australian Journal of Plant Physiology 23: 751-761.

van Lieshout, O. 1993. Consumer-oriented quality improvement of tomatoes in Indonesia: How construct an ideotype? How to assess quality problems? Euphytica 71: 161-180.

van Sanford, D.A. \& MacKown, C.T. 1986. Variation in nitrogen use efficiency among soft red winter wheat genotypes. Theoretical and Applied Genetics 72: 158-163.

Virgona, J.M. \& Barlow, E.W.R. 1991. Drought stress induces changes in the non-structural carbohydrate composition of wheat stems. Australian Journal of Plant Physiology 18: 239-247.

Welch, R.W. \& Leggett, J.M. 1997. Nitrogen content, oil content and oil composition of oat cultivars (A. sativa) and wild Avena species in relation to nitrogen fertility, yield and partitioning of assimilates. Journal of Cereal Science 26: 105-120.

Willenborg, C.J., Wildeman, J.C., Miller, A.K., Rossnagel, B.G. \& Shirtliffe, S.J. 2005. Oat germination characteristics differ among genotypes, seed sizes, and osmotic potentials. Crop Science 45: 2023-2029.

Willenbrink, J., Bonnett, G.D., Willenbrink, S. \& Wardlaw, I.F. 1998. Changes of enzyme activities associated with the mobilization of carbohydrate reserves (fructans) from the stem of wheat during kernel filling. New Phytologist 139: 471-478.

Woodend, J.J., Glass, A.D.M. \& Person, C.O. 1986. Intraspecific variation for nitrate uptake and nitrogen utilization in wheat ( $T$. aestivum L.) grown under nitrogen stress. Journal of Plant Nutrition 9: 1213-1225.

Wu, R.L. 1994. Quantitative genetics of yield breeding for Populus short rotation culture. III Efficiency of indirect selection on tree geometry. Theoretical and Applied Genetics 88: 803-811.

Wych, R.D. \& Stuthman, D.D. 1983. Genetic improvement in Minnesota-adapted oat cultivars released since 1923. Crop Science 23: 879-881. 


\title{
AGRICULTURAL AND FOOD SCIENCE
}

Mäkelä, P. et al. From ideotypes to cultivars in spring cereals

\section{SELOSTUS}

\section{Kevätviljat: ideotyypeistä pohjoisiin oloihin soveltuviksi lajikkeiksi}

\author{
Pirjo Mäkelä, Susanna Muurinen ja Pirjo Peltonen-Sainio \\ Helsingin yliopisto, Sokerijuurikkaan tutkimuskeskus ja MTT
}

Ideotyypillä tarkoitetaan kasvustoa, jossa yhdistyvät kaikki tarvittavat ja hyödylliset ominaisuudet hyvälaatuisen ja korkean sadon tuottamiseksi tietyssä kasvuympäristössä. Kasvuympäristön huomioiminen on erityisen tärkeätä ideotyyppiä hahmoteltaessa, sillä ilmastolla sekä edafisilla ja agronomisilla tekijöillä on keskeisin rooli kasvuston menestymisessä. Uudet viljelymenetelmät, ravinteet, satoisat lajikkeet, kastelu, kasvinsuojeluaineet sekä huolellinen viljelytoimien suunnittelu ja toteutus ovat parantaneet kevätviljojen satoja niin Suomessa kuin muuallakin maailmassa. Lajikkeita on kuitenkin kehitettävä edelleen erityisesti kasvinsuojeluaineiden ja typen käytön aiheuttaman ympäristökuormituksen vuoksi. Tarkastelemme tässä artikkelissa ominaisuuksia, jotka vaikuttavat keskeisesti elinvoimaisen ja hyvän kasvuston kehittymiseen ja menestymiseen ja samalla mahdollistavat panosten käytön vähentämistä kasvintuotannossa. Tarkastelun kohteena ovat siten kasvuston nopea ja elinvoimainen alkukehitys, sivuversojen muodostuminen, kääpiö- ja puolikääpiölajikkeet, veden- ja typenkäytön tehokkuus, korsivälivarastot sekä kasvuston kilpailukyky. Elinvoimainen kasvusto peittää maan nopeasti, mikä lisää kasvuston kilpailukykyä rikkakasveja vastaan ja samalla parantaa vedenkäytön tehokkuutta ja säästää maan vesivaroja. Kääpiömuotoja hyödyntämällä voidaan paitsi vähentää lakoutumista myös tehostaa hiiliyhdisteiden jakautumista kehittyviin jyviin korsien ja juurien sijaan. Keskittämällä sivuversojen muodostuminen yhteen tai kahteen tähkälliseen tai röyhylliseen sivuversoon voidaan edelleen tehostaa yhteyttämistuotteiden jakautumista sekä vedenkäyttöä. Erityistä huomiota tulisi kiinnittää kasvien kykyyn hyödyntää korsivälivarastoja jyväntäyttymisjakson aikana, koska sääolot ovat Suomessa usein hyvin vaihtelevat. Korsivälivarastoja hyödyntämällä jyväntäyttymistä voidaan jatkaa keskeytyksettä lähes sääoloista riippumatta. Kun kiinnitetään huomiota lajikkeiden valintaan ja viljelymenetelmiin, satotasoja ja keskisatoja on mahdollista nostaa Suomessa tulevaisuudessakin. 